\title{
Analysis of the Influence Factors Affecting the Development of Cross Border E-commerce in Gansu's Small and Medium Sized Foreign Trade Enterprises
}

\author{
Jing $\mathrm{Xu}^{1, \mathrm{a}}$ and Qiuping Song ${ }^{1}$ \\ ${ }^{1}$ School of economics, Northwest Minzu University, Lanzhou, Gansu, China
}

\begin{abstract}
This paper analyzes the macro and micro factors affecting the development of cross-border e-commerce enterprises in Gansu Province. It points out that there's sufficiency such as lack of funds and professional talents, poor competitiveness of products and fuzzy operation mode in the small and medium foreign trade enterprises in Gansu. It suggests that small and medium-sized foreign trade enterprises in Gansu should improve their own development, cultivate enterprises' e-business talents, enhance the market competitiveness of enterprise products, adopt multi style platform operation and improve relevant legal system.
\end{abstract}

Acknowledgement. This article is supported by the national information e-commerce key laboratory of Gansu province's higher education institutions. Also, it is the result of the opening phase of the laboratory of Northwest University for Nationalities (Project Approval No: SYSKF - 2018095).

In recent years, China's foreign trade conditions have been deteriorating. With the market demand in Europe and Japan continuously depressing the traditional export trade of China is increasing in a slow pace. In contrast, e-commerce has developed rapidly. The development speed of new trade represented by cross border electrical commerce has accelerated significantly. Compared with the traditional way of foreign trade, cross border e-commerce has the advantages of reducing production costs, reducing trade intermediaries, speeding up transaction and not being restricted by time and place, which attracts more enterprises to actively join in. At present, the small and medium sized foreign trade enterprises in Gansu Province should seize the historical opportunity of strategic idea of "The economic belt of the Silk Road" and the "one area and one road" policy to actively develop cross border e-commerce, which is the starting point of this article.

\section{Related concepts and research methods}

Cross border e-commerce is a new concept derived on the basis of e-commerce. It refers to the transaction, payment and settlement of transaction parties of different customs area through the e-commerce platform and an international trade activity to deliver goods and complete the transaction through the cross border logistics.

The main modes of cross border e-commerce are: One is the B2B model, which is the business model of exchanging and transferring data and information between enterprises and enterprises through Internet or special network. The second is the B2C model, which combines the enterprise and the consumer through the network. It provides all kinds of products to the consumer and brings the invisible pressure of competition to the service to the merchants. The third is the $\mathrm{C} 2 \mathrm{C}$ model, which provides an online trading platform for both buyers and sellers through e-commerce sites to enable the seller to publish information on the items to be sold on it, thus the buyer can choose to purchase from it. At the same time, in order to facilitate the transaction of both buyers and sellers, a series of necessarily supporting services are provided for the exchange.

The classification standard of small and medium-sized foreign trade enterprises has different standards in different countries and different industries. In our country, the enterprise generally refers to that whose workers are less than 500 or whose sales volume is less than 150 million yuan, engaged in foreign trade (import and export), and have the import and export business right of legal products within the related fields of the registered enterprises stipulated by the state.

This paper mainly uses factor analysis method to analyze the relevant micro and macro factors. The macro factors use PESTLE analysis method. PESTEL analysis, also known as environmental analysis, is a method to investigate the external influence factors affecting the organization, including political, economic, social,

a.Corresponding author: 1037007123@qq.com 
technical, environmental and legal factors.

\section{Research status at home and abroad}

Domestic scholars mainly take small and medium-sized foreign trade enterprises, cross-border e-commerce or e-commerce as the research object study on the development status, internal and external influence factors, cross border e-commerce mode selection factors and so on. [1] [2] [3] [4] [5] [6] [7] [8] Foreign scholars generally believe that cross border e-commerce plays a positive role in international trade, business operation and globalization, which can bring better business results to enterprises as well as put forward the conclusion that cross border payment system has brought comparative advantages to English exporting countries. [9] [10] [11] In summary, in recent years, there are many achievements in the literature of cross border e-commerce research, but they are mainly from the national level. While the cross border e-commerce literatures take Gansu Province as the starting point is hardly seen. This article takes the small and medium sized foreign trade enterprises in Gansu as the main subject, analyzes the influence factors affecting the development of the cross border e-commerce in the region and puts forward some countermeasures and suggestions.

\section{Analysis of influence factors affecting cross border electrical commerce of small and medium sized foreign trade enterprises in Gansu}

\subsection{Microcosmic factor analysis}

\subsubsection{The development of enterprises is not perfect and there are financial problems}

As the Gansu province is located in the west, the economic development is backward, the small and medium foreign trade enterprises start late and develop slowly. The enterprises have no strong capital strength, lacking of cross-border management consciousness. Their management methods are backward and the financial system is unsound. The long-term strategic objectives are unreasonable and undefined. The enterprises plunged fixed assets in the process of enterprise transportation. They pay more attention to profits while neglecting management of cash flow. The investment is too high, which leads to insufficient accumulation and impedes the development of enterprises.

\subsubsection{Lack of professional talents in enterprises}

With the rapid development of e-commerce industry, the requirements of cross border e-commerce professional talents are also increasing. High and new technology talents have become the key elements for the development and upgrading of competitiveness of small and medium sized enterprises of cross border e-commerce industry. Small and medium sized foreign trade enterprises in Gansu province have been restricted by talents factor in the process of carrying out cross border e-commerce. Due to the problems that they are in the western region, small scale, slow development speed, weak capital and technical strength, it is difficult for them to attract high quality comprehensive talents. Most people are more willing to choose the large enterprises in the eastern coastal areas to work. In addition, the development time of small and medium sized foreign trade enterprises in Gansu is not long. Most of the employees have not received technical training systematically and lack market data analysis ability. The data utilization rate on cross border e-commerce is very low.

\subsubsection{The market competitiveness of the enterprise's own product is not strong}

Cross border e-commerce products are mainly clothing, cosmetics, luxury goods, accessories and agricultural products, which are easy to open up the market and sold widely. The main products of Gansu province are mainly special agricultural products, Muslim food, base metal and their finished products, national products and so on. The product type is single, the special consumption group is formed. The export volume of the enterprise is limited by the target market. In addition, the reprocessing degree of products of most enterprises in Gansu is low and the value-added of the industrial chain is low. They can only seize the market and customers at low price and lack the construction of enterprise brand and product brand. They are in a low profit level.

\subsubsection{Enterprise operation model is inexplicit}

Gansu Province, cross border e-commerce started late, many small and medium sized enterprises lack knowledge of this new business model, but also see the market prospects, blindly follow the wind to transform. They just set up a website, put up a few ads to sit and wait for customers order, failure is unavoidable.

\subsection{Macro factor analysis}

\subsubsection{Political factors}

According to the spirit of [2013] 89 documents issued by the State Office, under the guidance of government promotion, market operation, policy support and mechanism innovation, the small and medium sized foreign trade enterprises in Gansu have a good domestic political environment. With the deployment of the "along the way" economic strategy, Gansu should seize the opportunity to enhance the image of the international market and further expand its export volume. On the other hand, in the international market, there is still pressure on the political environment abroad. With the improvement of China's status in the international market, some big trade countries restrain our foreign trade 
through trade protection, for example, by collecting income tax on personal income, increasing the product tax of our export commodities, import restrictions, price control, foreign exchange control and nationalization policy, and so on, to obstruct the development of small and medium sized foreign trade enterprises cross border e-commerce in Gansu.

\subsubsection{Economic factors}

From 2013 to 2017, Gansu's GDP increased slowly and its growth rate declined. In the three industry, the primary industry grew slowly, the second industry declined and the third industry grew rapidly. Gansu is an important base of energy and heavy chemical industry in China. Petrochemical, non-ferrous, metallurgical and coal industries are traditional industries. For small and medium-sized foreign trade enterprises, the types of products are limited, they are lack of competitiveness in the international market, the export volume is small and downward trend.

\subsubsection{Social factors}

Gansu is an inhabited area of many ethnic minorities. The export products of some small and medium-sized foreign trade enterprises are mainly ethnic products. At the same time, the population of Gansu province has the characteristics of flowing from backward areas to developed areas, from inland cities to coastal cities, the migration of rural labor force within the province and the migration of talents. These restrict the product type and talent introduction of small and medium sized foreign trade enterprises in Gansu province.

\subsubsection{Technical factors}

The development of cross border e-commerce from traditional intermediary participation in transactions to cross-temporal network-side transactions requires higher e-commerce professional skills of relevant personnel. However, because of the historical and geographical factors of small number of key universities, the weak capital strength of small and medium-sized foreign trade enterprises, and so on, Gansu province is at a disadvantage in the contention of talent in the Middle East region, there is a serious lack of electronic commerce professionals.

\subsubsection{Environmental factors}

Gansu province is located in the northwest of China. It does not have the convenient marine transportation conditions in the eastern coastal cities. There is no perfect infrastructure for medium and small foreign trade enterprises to develop cross border e-commerce. The information circulation is not timely, the development of foreign trade is hindered and the cross border business development of small and medium foreign trade enterprises in Gansu is also restrained.

\subsubsection{Legal factors}

Cross border e-commerce is a new mode of trade, which involves a wide range of customs, taxes and business laws in different countries. There is no perfect legal system to match it. The development of cross-border e-commerce in Gansu Province started late, has little experience, and the construction of laws and regulations is not perfect, which also causes a series of legal risks about privacy, transactions.

\section{Countermeasures and suggestions}

\subsection{The enterprise consummates its own development}

The small and medium foreign trade enterprises in Gansu should actively study the management ideas and management methods of the outstanding foreign trade enterprises in the developed cities of the Middle East, perfect the financial management system of the enterprises themselves, choose the investment carefully by formulating the long-term strategic objectives suitable for the market and control the cash expenditure and inflow accurately.

\subsection{Cultivating professional e-business talents}

Gansu should also carry out personnel training and introduction at the same time to ease the bottleneck of the supply of e-commerce talents at all levels. To speed up the formation of e-business personnel training system, which is the main body of relevant government departments, social groups and higher (vocational) colleges and universities, run a good professional training institution such as Taobao University (Gansu). They should also encourage colleges and universities to dock with enterprises, build a training and practice base for e-business talents, increase the strength of the introduction of outstanding electronic business talents outside the province. Efforts should be made to implement the policy of promoting the introduction of various talents. Large and medium-sized foreign trade enterprises in the selection of enterprise personnel should in accordance with a certain standard screening and carry out centralized pre-job training to enhance employees' working ability.

\subsection{Enhancing the market competitiveness of enterprises' product}

When choosing the main commodities, the small and medium foreign trade enterprises in Gansu should analyze the domestic and foreign markets accurately and make use of the unique political advantages, national advantages and industrial advantages of Gansu province to formulate appropriate product management strategies. At the same time, cultural differences such as consumer preferences and festivals in different countries also affect the market positioning of small and medium-sized foreign trade enterprises. By launching products on the new 
technology platform, change the product competition to property rights competition.

\subsection{Adaptation of multi style platform operation}

Small and medium-sized foreign trade enterprises in Gansu should vigorously foster the local e-commerce platform. They should support the development of local e-business platforms such as agricultural products, Chinese medicinal materials, Muslim food and national supplies. Relying on regional industrial clusters to develop a batch of industrial vertical e-commerce platform and commodity trading platform; Support the transformation of the e-business platform of the large leading enterprises to the industry platform. Combined with the development trend of mobile e-commerce, it supports the development of mobile platform in the field of local life service, micro-blog, WeChat new media platform, micro e-commerce platform, group buying platform and $\mathrm{O} 2 \mathrm{O}$ platform.

\subsection{Improving the relevant legal system}

The state and local governments should revise the relevant laws and regulations of foreign trade as soon as possible, further establish and perfect our foreign trade promotion system, establish and improve the trade defense and trade relief measures, improve the transparency of laws and regulations.

The cross border e-commerce is a sunrise business after the development of "Internet $+"$. The small and medium sized foreign trade enterprises in Gansu should break through the problems of regional limitation and lack of development. We should make use of unique geographical location and natural conditions to develop the cross-border e-commerce and brand construction of special products, and formulate reasonable strategic goals and marketing strategies.

\section{References}

1. Yang Jianzheng. Application analysis of cross border e-commerce in China's foreign trade enterprises [J]. Contemporary economic management, (2014).

2. Yang Nachuan. Analysis of influence factors affecting cross-border e-commerce in small and medium sized enterprises [J]. E-commerce, (2015).

3. Lu Xudong. The influence factors of cross border electrical commerce development in big data era [J]. Economic and trade practice, (2015).

4. Zhu Kai. China's cross border electrical commence development status analysis and related suggestions [J]. Modern business, (2014).

5. Li Yueqiao. Opportunities and challenges faced by China's small and medium sized foreign trade enterprises in cross border electrical commerce [J]. Hebei University of Economics and Business, (2016).

6. Xu Mengmeng. Current situation and problems of cross border electrical commerce development in China [D]. Anhui University, (2016).

7. Wang Yanli, Du Jimeng, Liu Zhixiang. The status quo, problems and upgrading ways of cross border electrical commerce [J]. Business Economics Research, (2016).

8. Li Wen. Analysis of the development of cross border e-commerce B2B mode [D]. Jilin University, (2017).

9. Lal, E-business and Export Behaviour Evidence from Indian Firms [J].World Development, 2004.

10. Lue Cassivi, Michael Wybo, Pierre-Majorique Leger and Pierre Hadaya. The level of International Business and its Association with Different Internet E-commerce Practices [J]. IEEE Computer Society, 2010.

11. The drivers and impediments for cross-border e-commerce in the EU [J]. Estrella Gomez-Herrera, Bertin Martens, Geonmina Turlea. Information Economics and Policy, 2014. 